\title{
Effects of Exposure to Two Fragrances on the Gene Expression of Ckm and Ckmt2 and Total CK Activity in the Hearts of Wistar Rats
}

\author{
Gbenga Anthony Adefolaju, ${ }^{1, *}$ Benedict Abiola Falana, ${ }^{2}$ and Moyosore Salihu Ajao ${ }^{1}$ \\ ${ }^{1}$ Department of Anatomy, Faculty of Basic Medical Sciences, College of Health Sciences, University of Ilorin, Ilorin, Nigeria \\ ${ }^{2}$ Department of Anatomy, Faculty of Basic Medical Sciences, College of Health Sciences, Osun State University, Osogbo, Nigeria \\ "Corresponding author: Gbenga Anthony Adefolaju, Department of Anatomy, Faculty of Basic Medical Sciences, College of Health Sciences, PMB 1515, University of Ilorin, Ilorin, \\ Nigeria. E-mail: gbenga.adefolaju@wits.ac.za
}

Received 2014 December 29; Accepted 2015 January 7.

\begin{abstract}
Background: Some of the most commercially used compounds in fragrances have been associated with various adverse effects in various experimental in vivo and in vitro models and are still being used promiscuously in perfumes and as additives in other household products.

Objectives: This study sought to determine the effects of exposing wistar rats to two locally made Nigerian perfumes on some cardiac performance enzyme and genes.

Materials and Methods: In this experimental study, 18 animals were allocated into three groups (A, B and C) of six each. Groups B and $C$ animals were exposed (by inhalation) to the first and second perfumes (designated F1 and F2) respectively for 77 days, while animals in group A were unexposed control. The rats were sacrificed at the end of the exposure period after which heart tissue was excised for creatine kinase enzyme assay and formalin fixed, paraffin embedded heart tissues were processed for RNA extraction and analyzed by quantitative real time polymerase chain reaction for the mRNA expression of creatine kinase genes Ckm and Ckmt2.

Results: The results showed that animals in both exposure groups demonstrated significantly $(\mathrm{P}<0.05)$ increased expression of striated muscle associated creatine kinase and sarcomeric mitochondria Ck genes as well as the increased release of the cardiomyocyte enzyme CK in the hearts of Wistar rats.
\end{abstract}

Conclusions: These results suggest that exposure to these two locally made fragrances contributes to cardiomyocyte stress.

Keywords: Creatine Kinase, Perfume, Rats, Heart, mRNA Expression, Ckm, Ckmt2

\section{Background}

Fragrances are widely used and they contain anthropogenic nitrobenzene derivatives [1]. Some of the most commercially used compounds in fragrances include musk moskene (MM) (1, 1, 3, 3, 5-pentamethyl-4, 6-dinitro-2H-indene), musk tibetene (MT) (1-tert-butyl-3, 4, 5-trimethyl-2, 6-dinitrobenzene), musk ambrette (MA) (2, 6-dinitro-3-methoxy-4-tert-butyltoluene), musk ketone (MK) (4-tert-butyl-2, 6- dimethyl-3, 5-dinitroacetophenone) and musk xylene (MX) (1-tert-butyl-5-dimethyl-2, 4, 6trinitrobenzene) [1]. MM and MT have been banned in the United States [1] and MA has been associated with various adverse effects in rats such as hind limb weaknesses and pathologic effects on neural tissue [2]. MK and MX however are still being used promiscuously in perfumes and as additives in household cleaning products and other fragrant non-cosmetic products [3]. The European Commission Joint Research Centre Institute for Health and Consumer Protection in 2008 classified MK and MX as environmentally ubiquitous, very persistent and very bio-accumulative compounds which are not easily bio-degradable [4].

Creatine kinase (CK), also referred to as creatine phosphokinase (CPK) or phospho-creatine kinase is an enzyme that catalyses the conversion of creatine (utilising adenosine triphosphate (ATP)) to phosphocreatine (PCr) and adenosine diphosphate (ADP). The reaction allows for reversible ATP generation [5].

In tissues and cells that consume ATP rapidly, especially brain and striated muscles, PCr serves as an energy reservoir for the rapid buffering and regeneration of ATP in situ, and for intracellular energy transport $[5,6]$. CK exists in three cytosolic and two mitochondria isoforms. Isoform patterns occur differently in tissues. In the cytosol are CKB (brain type), CKM (muscle type) and CKMB (mixed type); and in the mitochondria are ubiquitous mitochondrial CK (uMtCK) and sarcomeric MtCK (Ckmt2) [6]. CKB (brain) is expressed in all tissues at low levels and has little known clinical significance. Skeletal muscle expresses CKM (over 95\%) and low levels of CKMB (1\%). Cardiac muscle expresses CKM at 70\% and CKMB at 25\% - 30\% [5, 6]. Clinically, CK is assayed as a screening test for suspected muscle disease in- 
cluding myocardial infarction, rhabdomyolysis, muscular atrophy and acute renal failure. It is a useful diagnostic test because its levels are not falsely raised by haemolysis, and is readily released by cellular injury because it is unbound in the cytosol [5].

In Nigeria and around the world, even though the precise formulae of commercial perfumes are kept as trade secrets, the effects of these fragrance products on myocardial function need to be properly elucidated. This is because consumers of fragrance products are habitually and intentionally exposed to the complex mixtures found in perfume products $[1,3]$. A thorough literature search did not provide studies investigating the effects of fragrance products on cardiac muscle stress.

\section{Objectives}

This study was designed therefore to determine the effects of exposure to two locally made perfumes; ("Miyaki" and "Cool River" designated F1 and F2 respectively) on the gene expression of Ckm and Ckmt2 and the activity levels of total CK in the hearts of Wistar rats.

\section{Materials and Methods}

\subsection{Animals, Grouping and Treatment}

In this experimental study, the maintenance and care of experimental animals complies with national institutes of health guidelines for the humane use of laboratory animals and approval was obtained from the College of Health Sciences research committee, university of Ilorin, Nigeria. Eighteen healthy male Wistar rats (average weight $148 \mathrm{~g}$ ) were obtained from and kept at the animal holdings unit of the department of anatomy, university of Ilorin in well ventilated cages under standard photoperiodic conditions and given rat pellets (Bendels Feeds, Yoruba road, Ilorin) and water ad libitum. Rats were divided into three groups labeled A, B and C. Group A is the control group while B and $C$ were the experimental groups. All groups consist of 6 rats each. During each day of administration, $5 \mathrm{~mL}$ of each perfume (F1 for group B and F2 for group $C$ and 5 $\mathrm{mL}$ of distilled water for group A) was injected into balls of cotton wool. The cotton wool was placed in a perforated container so as to prevent the rats from eating the soaked cotton wool. The rats were exposed to the fragrance of perfumes for 6 hours daily after which they were returned to their respective cages. The administration was conducted for 77 days. After exposure, hearts were excised, rinsed in ice-cold isotonic saline, blotted with filter paper, and homogenized for CK activity. Portions of the hearts were also removed and fixed in 10\% formalin solution for paraffin embedding.

\subsection{Creatine Kinase Activity Assay}

According to the CK Activity Colorimetric Assay kit, CK converts creatine into phosphocreatine and ADP. The generated phoshocreatine and ADP reacts with CKenzyme mix to form an intermediate, which reduces a colorless probe to a colored product with strong absorbance at $450 \mathrm{~nm}$. The manufacturer's protocol was followed for the assay, briefly; $10 \mathrm{mg}$ of heart tissue was rapidly homogenized with $100 \mu \mathrm{L}$ ice cold assay buffer for 10 minutes on ice. The homogenate was centrifuged at $12000 \mathrm{rpm}$ for 5 minutes. The supernatant was collected and $10 \mu \mathrm{L}$ of the sample was added per well of a 96-well Falcon tissue culture plate. The final volume was adjusted to $50 \mu \mathrm{L}$ with assay buffer. For the positive control, $10 \mu \mathrm{L}$ of positive control was added into appropriate wells and final volume adjusted to $50 \mu \mathrm{L}$ with assay buffer. Fifty (50) $\mu \mathrm{L}$ of the reaction mix was added to each well containing the standard, positive control and samples, mixed well, incubated for 30 minutes at $37^{\circ} \mathrm{C}$ and the optical density was measured in a microplate reader (Anthos 2010 model 17-550 Austria) at a wavelength of $450 \mathrm{~nm}$.

\subsection{Quantitative Real-Time PCR}

Extraction of total RNA from formalin fixed, paraffin embedded tissue was performed as described by Ma et al. [7]. The total RNA was precipitated by mixing with $0.6 \mathrm{~mL}$ isopropyl alcohol, and placed at $-20^{\circ} \mathrm{C}$ for 1 hour and then centrifuged at $12000 \times \mathrm{g}$ for 10 minutes at $4^{\circ} \mathrm{C}$. RNA pellet was washed with $100 \%$ ethanol, briefly air-dry and dissolved in RNase-free water. RNA concentration and purity were determined by using the Nanodrop-1000 spectrophotometer. RNA integrity was checked by gel electrophoresis. According to the manufacturer's instructions, genomic DNA was removed from total RNA using the DNase I, RNasefree kit. The DNase I treated RNA was again cleaned with the Gene JET RNA Purification kit, re quantified and stored at $-80^{\circ} \mathrm{C}$ until used. According to the manufacturer's instructions, cDNA was synthesized using the MultiScribe ${ }^{\mathrm{TM}}$ Reverse Transcriptase from 500 ng RNA. The reverse transcriptase reaction was carried out in a GeneAmp® PCR System 9600 Thermal Cycler for 10 minutes at $25^{\circ} \mathrm{C}, 120 \mathrm{~min}$ utes at $37^{\circ} \mathrm{C}$ and then the enzyme was deactivated for $5 \mathrm{~min}$ utes at $85^{\circ} \mathrm{C}$. The cDNA aliquots were then utilized in qPCR reactions for Ckm, with Sdha, Actb and B2m used as the endogenous reference genes. PCR reactions were amplified for 40 cycles prior to which the AmpliTaq Gold $₫$ DNA polymerase was activated for 10 minutes at $95^{\circ} \mathrm{C}$. Each cycle consisted of a denaturing step for 15 second at $95^{\circ} \mathrm{C}$ and annealing/extension step for 1 minutes at $60^{\circ} \mathrm{C}$. PCR amplification was performed in a final volume of $20 \mu \mathrm{L}$ using the Power SYBR@ Green PCR Master Mix with the ABI 7500 
real-time PCR machine. Primer sequences and PCR product sizes are indicated in Table 1. Primers were designed with NCBI/Primer3 and BLAST.

Table 1. Oligonucleotide Sequences Used for Qpcr

\begin{tabular}{|c|c|c|c|}
\hline \multicolumn{2}{|c|}{$\begin{array}{l}\text { Gene and Sequences (5'-3' } \\
\text { Direction) }\end{array}$} & \multirow{2}{*}{$\begin{array}{c}\text { NCBI Accession No. } \\
\text { NM_012530.2 }\end{array}$} & \multirow{2}{*}{$\begin{array}{c}\text { Product Size, bp } \\
123\end{array}$} \\
\hline Ckm & & & \\
\hline & $\begin{array}{l}\text { F: CAC CCC TTC ATG TGG } \\
\text { AAC GA }\end{array}$ & & \\
\hline & $\begin{array}{l}\text { R: CTC AAA CTT GGG GTG } \\
\text { CTT GC }\end{array}$ & & \\
\hline \multirow[t]{3}{*}{ Ckmt2 } & & NM_001127652.1 & 79 \\
\hline & $\begin{array}{l}\text { F: CCC CCA AGT GCA GAC } \\
\text { TAT CC }\end{array}$ & & \\
\hline & $\begin{array}{l}\text { R: TGG CAT AGA TGG TTG } \\
\text { GGG TG }\end{array}$ & & \\
\hline \multirow[t]{3}{*}{ Sdha } & & NM_130428.1 & 102 \\
\hline & $\begin{array}{l}\text { F: CCC ATT CCA GTC CTT } \\
\text { CCC AC }\end{array}$ & & \\
\hline & $\begin{array}{l}\text { R: CAC AAT CTG ATC CTG } \\
\text { GCC GT }\end{array}$ & & \\
\hline \multirow[t]{3}{*}{ Actb } & & NM_031144.3 & 134 \\
\hline & $\begin{array}{l}\text { F: CTG TGT GGA TTG GTG } \\
\text { GCT CT }\end{array}$ & & \\
\hline & $\begin{array}{l}\text { R: AGC TCA GTA ACA GTC } \\
\text { CGC CT }\end{array}$ & & \\
\hline \multirow[t]{3}{*}{ B2m } & & NM_012512.2 & 170 \\
\hline & $\begin{array}{l}\text { F: CAC ACG CAG TCT GAA } \\
\text { AAC CC }\end{array}$ & & \\
\hline & $\begin{array}{l}\text { R: AAA GGA GCT TTG GGG } \\
\text { ACA CA }\end{array}$ & & \\
\hline
\end{tabular}

To confirm the absence of nonspecific amplification, PCR products were separated on 3\% agarose gels, stained with ethidium bromide and images acquired with the BioRad Gel Doc® XR (Model 170-8170 Segrate, Milan, Italy). Melt curves were generated for each PCR product using the Applied Biosystems ABI 7500 software. The relative mRNA expression levels of target genes in each sample were calculated using the qbasePLUS software (Biogazelle, Zulte, Belgium).

Statistical Analysis: Statistical analysis was performed using JMP® (Version 10.0 SAS Institute Inc., Cary, NC). Data are reported as mean $\pm S E M$. After verifying the normal distribution and the homogeneity of the variance using an Ftest $(\mathrm{p}<0.05)$, a one way analysis of variance (where a significance level of $\mathrm{P}<0.05$ was set) was used to compare the results. All means were then compared using the TukeyKramer HSD.

\section{Results}

Total CK activity: Levels of creatine kinase (CK); indices of cardiac cellular damage, were assessed and found to be significantly $(\mathrm{P}=0.0001)$ higher in rat groups exposed to both fragrances for 77 days as compared to the control groups (Figure 1).

Figure 1. Effects of F1 and F2 on Creatine Kinase Level in rat Hearts After 77 Days Exposure

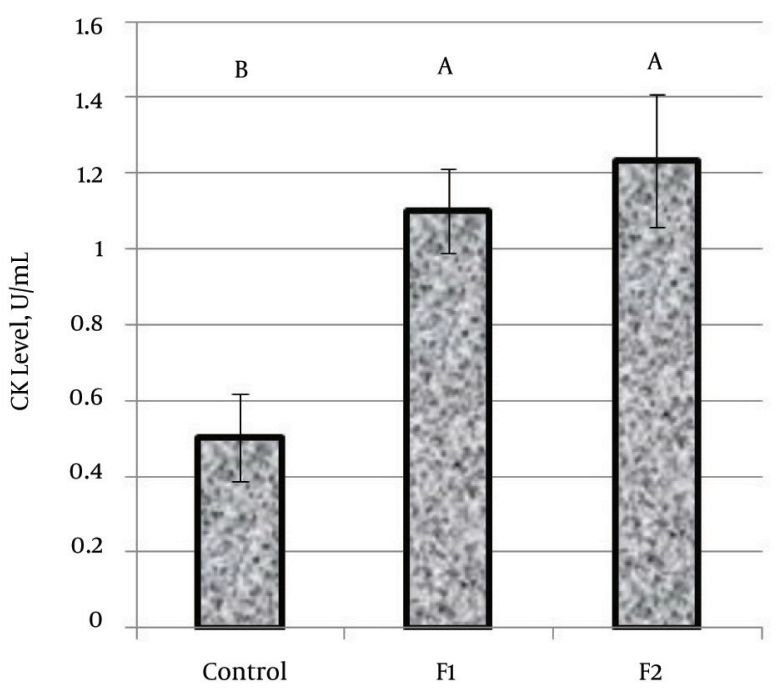

Data (mean \pm SEM) are CK activity $(\mathrm{U} / \mathrm{mL})$ representative of 3 independent experiments. Groups not connected by the same letter are significantly $(\mathrm{P}<0.05)$ different.

\subsection{Expression of Ckm and Ckmt2 Genes}

The mRNA expressions of the two creatine kinase isoforms investigated were found to be significantly altered in the groups of animals exposed to both fragrances. Ckm mRNA was significantly $(\mathrm{P}=0.0001)$ up regulated in rat groups exposed to both fragrances (Figure 2). Striated muscle associated sarcomeric mitochondrial CK mRNA was also significantly $(\mathrm{P}=0.0001)$ up regulated in both fragrance exposed groups (Figure 2).

\section{Discussion}

The increased expression of striated muscle associated creatine phosphokinase and sarcomeric mitochondria Ck genes as well as the increased release of the cardiomyocyte enzyme CK in the hearts of Wistar rats suggests that exposure to these two locally made fragrances contributes to cardiomyocyte stress. Creatine kinase is involved in the 
Figure 2. Effects of F1 and F2 on Ckm and Ckmt2 mRNA Expression in Rat Hearts After 77 Days Exposure

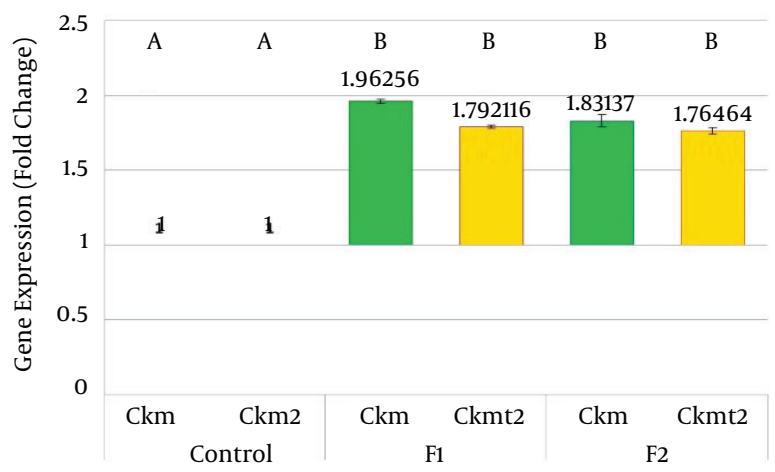

Data (mean \pm SEM), are represented as fold changes of gene expression relative to values from control group (defined as 1 ) and representative of 3 independent experiments for RNA.

maintenance of striated muscle intracellular energy supply through its ATP buffering capabilities $[8,9]$. Ck thus play very important roles in tissues requiring fluctuating and enormous energy demands like cardiac muscle and brain, with the mitochondrial isoform of CK (MtCK) required for the energetics of oxidative tissue [9].

The production of reactive oxygen and nitrogen species (ROS, RNS) is central to the pathophysiology of myocardial injury $[9,10]$ and this is often characterized by oxidative damage, poor energetic state of tissues, calcium overload and increased apoptosis. The impairment of CK isozymes by ROS/RNS leads to the interruption of the CK/phosphocreatine-shuttle and cause impaired cellular energy dynamics [9]. Upregulation of CK isozymes in the rat hearts has been associated with stress by chronic restrain, demonstrating cardiac malfunction, impaired mitochondrial respiration and apoptosis [11].

Consumers of fragrance products are habitually and intentionally exposed to the complex mixtures found in perfume products $[1,3,12]$. The chemical mixtures of fragrance products may contain 100 or more fragrance raw materials (FRMs) at concentrations of $1 \%$ or greater. Many previous toxicology studies [13-16] assessed the hazards of exposure to just one to three components out of the numerous compounds contained in the perfume mixtures, whereas actually, humans are exposed to the complex numbers of chemicals contained in fragrance mixtures [12]. One of the objectives of this study therefore was to evaluate the safety of the prolonged use of finished fragrance products via the inhalation route in rats. A thorough literature search did not provide studies investigat-
Figure 3. Agarose Gel Electrophoresis of PCR Products Confirming the Absence of Nonspecific Amplification

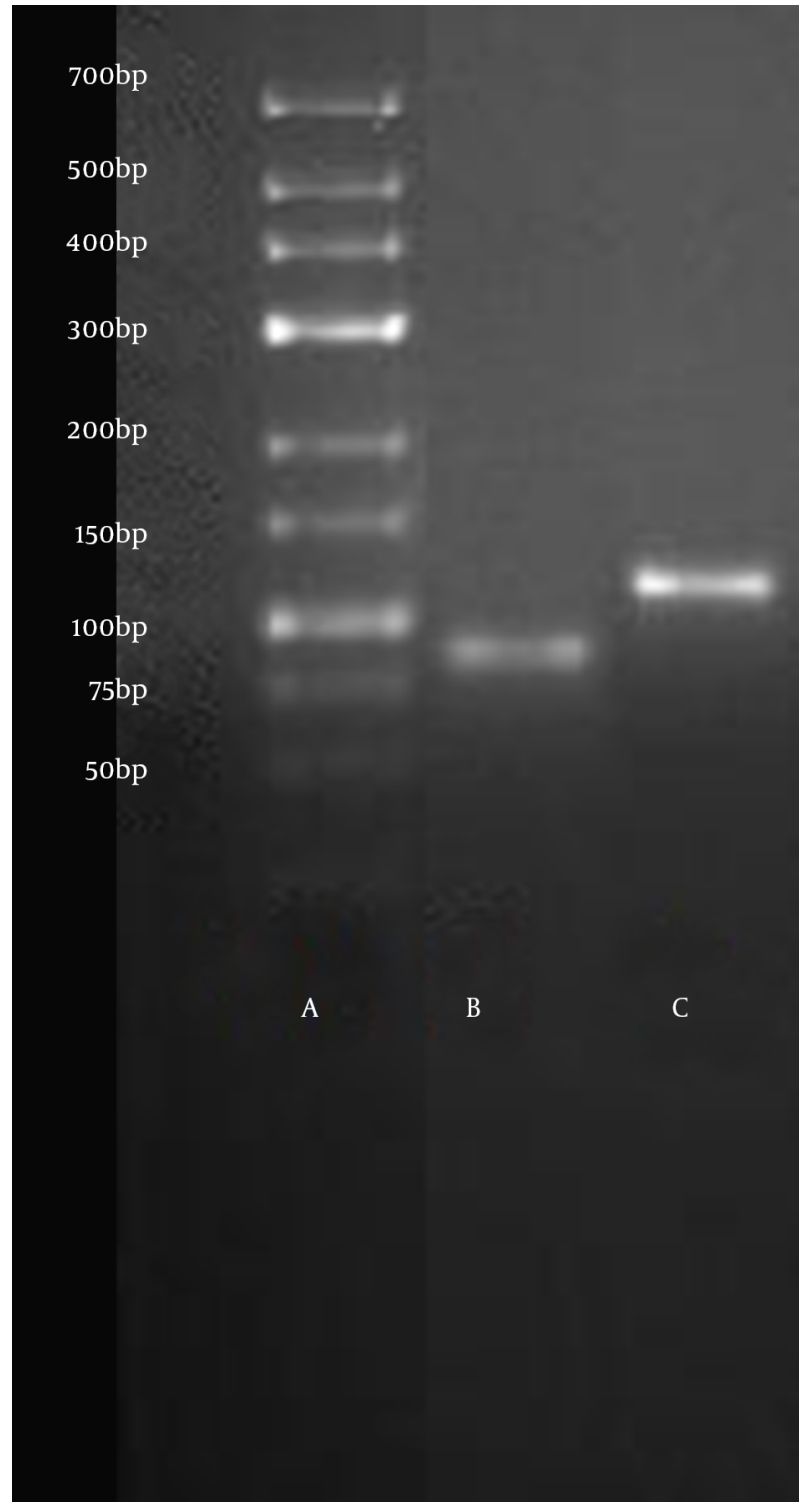

Lane A, DNA Ladder (O'GeneRuler Low Range -Thermo Scientific, Pittsburgh PA, USA) Range: $25 \mathrm{bp}$ to $700 \mathrm{bp}$; lane B, Ckmt2 PCR product size (79 bp); lane C, Ckm PCR product size (123 bp).

ing the effects of fragrance products on cardiac muscle stress. Many studies however were found demonstrating the developmental, carcinogenic and human endocrine effects of fragrance compounds [12, 14, 16]. Carlsson et al. [13] reported that MK levels of $0.1-10 \mathrm{mg} / \mathrm{g}$ of food per day reduced the body weight of spawning females as much as 38\% and reduced the number of eggs per female per day as much as $95 \%$ in zebra fish. South African clawed 
frogs exposed to $400 \mu \mathrm{g} / \mathrm{L} /$ day of $\mathrm{MK}$, MX or MM in the surrounding water for eleven days demonstrated increasing larvae mortality for each increasing day of exposure [17]. The lipophilicity of nitro musks has raised concerns over their possible endocrine modulating effects. When human MCF-7 breast cancer cells were exposed to MX or MK in surrounding media, there was a significant increase in the proliferation of the human breast cancer cells by $29 \%$ for MX and by $97 \%$ for MK when compared to the negative control [14]. While various genotoxicity studies (Api and Gudi, Kevekordes et al.) in Escherichia. coli PQ27 cells, human hepatoma, human lymphocytes cell lines and rats indicated that nitro musks were not genotoxic [18-20], it has been suggested that other in vivo processes might be occurring to promote tumorigenesis as shown by the report of Maekawa et al. [21], which found that mice fed with food containing $0.075 \%$ or $0.15 \%$ MX had three times as many tumors compared to control mice.

In this study, we report that levels of creatine kinase (CK) and the mRNA expressions of two creatine kinase isoforms (Ckm and Ckmt2); important indices of cardiac cellular damage, were assessed and found to be significantly higher in rat groups exposed to two locally made Nigerian perfumes.

\section{Acknowledgments}

The authors acknowledge Mrs H Ali, school of anatomical sciences, medical school, university of the Witwatersrand, Johannesburg, south Africa for her assistance with PCR and gel electrophoresis.

\section{Footnotes}

Authors' Contribution: Gbenga Anthony Adefolaju, Benedict Abiola Falana and Moyosore Salihu Ajao for conceptualisation of study and experimental design; standardization and optimisation of all protocols; Data acquisition, analysis and interpretation; Manuscript write-up and final approval of the submitted version.

Funding/Support: The work received support from the Nigerian government tertiary education trust fund awarded FBA.

\section{References}

1. Ford RA, Domeyer B, Easterday O, Maier K, Middleton J. Criteria for development of a database for safety evaluation of fragrance ingredients. Regul Toxicol Pharmacol. 2000;31(2 Pt 1):166-81. doi: 10.1006/rtph.1999.1362. [PubMed: 10854123].

2. Spencer PS, Bischoff-Fenton MC, Moreno OM, Opdyke DL, Ford RA. Neurotoxic properties of musk ambrette. Toxicol Appl Pharmacol. 1984;75(3):571-5. [PubMed: 6474483].
3. Roosens L, Covaci A, Neels H. Concentrations of synthetic musk compounds in personal care and sanitation products and human exposure profiles through dermal application. Chemosphere. 2007;69(10):1540-7. doi: 10.1016/j.chemosphere.2007.05.072. [PubMed: 17631381].

4. Verbruggen ESD, Van Iersel P, Schwarz-Schulz B, editors. PBT Assessment of 5-Tert-Butyl-2,4,6-Trinitro-M-Xylene (Musk Xylene) Addendum to the final risk assessment report.. European Commission Joint Research Centre Institute for Health and Consumer Protection. 2008; Italy. JRC technical and scientific reports; p. 2010 -24.

5. Gasper MC, Gilchrist JM. Creatine kinase: a review of its use in the diagnosis of muscle disease. Med Health R I. 2005;88(11):398. [PubMed: 16363394] 400-4.

6. Kwon S, Kim D, Rhee JW, Park JA, Kim DW, Kim DS, et al. ASB9 interacts with ubiquitous mitochondrial creatine kinase and inhibits mitochondrial function. BMC Biol. 2010;8:23. doi: 10.1186/1741-7007-8-23. [PubMed: 20302626].

7. Ma Z, Lui WO, Fire A, Dadras SS. Profiling and discovery of novel miRNAs from formalin-fixed, paraffin-embedded melanoma and nodal specimens. J Mol Diagn. 2009;11(5):420-9. doi: 10.2353/jmoldx.2009.090041. [PubMed: 19710399].

8. Fredericks S, Murray JF, Carter ND, Chesser AM, Papachristou S, Yaqoob MM, et al. Cardiac troponin T and creatine kinase MB content in skeletal muscle of the uremic rat. Clin Chem. 2002;48(6 Pt1):859-68. [PubMed: 12029001].

9. Schlattner U, Tokarska-Schlattner M, Wallimann T. Mitochondrial creatine kinase in human health and disease. Biochim Biophys Acta. 2006;1762(2):164-80. doi: 10.1016/j.bbadis.2005.09.004. [PubMed: 16236486].

10. Raedschelders K, Ansley DM, Chen DD. The cellular and molecular origin of reactive oxygen species generation during myocardial ischemia and reperfusion. Pharmacol Ther. 2012;133(2):230-55. doi: 10.1016/j.pharmthera.2011.11.004. [PubMed: 22138603].

11. Liu XH, Qian LJ, Gong JB, Shen J, Zhang XM, Qian XH. Proteomic analysis of mitochondrial proteins in cardiomyocytes from chronic stressed rat. Proteomics. 2004;4(10):3167-76. doi: 10.1002/pmic.200300845. [PubMed: 15378698].

12. Taylor KM, Weisskopf M, Shine J. Human exposure to nitro musks and the evaluation of their potential toxicity: an overview. Environ Health. 2014;13(1):14. doi: 10.1186/1476-069X-13-14. [PubMed: 24618224].

13. Carlsson G, Orn S, Andersson PL, Soderstrom H, Norrgren L. The impact of musk ketone on reproduction in zebrafish (Danio rerio). Mar Environ Res. 2000;50(1-5):237-41. [PubMed: 11460697].

14. Bitsch N, Dudas C, Korner W, Failing K, Biselli S, Rimkus G, et al. Estrogenic activity of musk fragrances detected by the E-screen assay using human mcf-7 cells. Arch Environ Contam Toxicol. 2002;43(3):25764. doi: 10.1007/s00244-002-1192-5. [PubMed: 12202919].

15. Luckenbach T, Epel D. Nitromusk and polycyclic musk compounds as long-term inhibitors of cellular xenobiotic defense systems mediated by multidrug transporters. Environ Health Perspect. 2005;113(1):17-24. [PubMed: 15626642].

16. Schnell S, Martin-Skilton R, Fernandes D, Porte C. The interference of nitro- and polycyclic musks with endogenous and xenobiotic metabolizing enzymes in carp: an in vitro study. Environ Sci Technol. 2009;43(24):9458-64. doi: 10.1021/es902128x. [PubMed: 19928757].

17. Chou YJ, Dietrich DR. Interactions of nitromusk parent compounds and their amino-metabolites with the estrogen receptors of rainbow trout (Oncorhynchus mykiss) and the South African clawed frog (Xenopus laevis). Toxicol Lett. 1999;111(1-2):27-36. [PubMed: 10630701].

18. Api AM, Gudi R. An in vivo mouse micronucleus assay on musk ketone. Mutat Res. 2000;464(2):263-7. [PubMed:10648913].

19. Kevekordes S, Grahl K, Zaulig A, Dunkelberg H. Nitro musk compounds genotoxic activity: Genotoxicity testing of nitro musks with the SOS-chromotest and the sister-chromatid exchange test. Environ Sci Pollut Res Int. 1996;3(4):189-92. doi:10.1007/BF02986953. [PubMed: 
24233413].

20. Kevekordes S, Zaulig A, Dunkelberg H. Genotoxicity of nitro musks in the micronucleus test with human lymphocytes in vitro and the human hepatoma cell line Hep G2. Toxicol Lett. 1997;91(1):13-7. [PubMed: 9096281].

21. Maekawa A, Matsushima $Y$, Onodera $H$, Shibutani M, Ogasawara $H$ Kodama Y, et al. Long-term toxicity/carcinogenicity of musk xylol in B6C3F1 mice. Food Chem Toxicol. 1990;28(8):581-6. [PubMed: 2242833]. 